\title{
Conservation hotspots: implications of intense spatial area use by breeding male and female loggerheads at the Mediterranean's largest rookery
}

\author{
Gail Schofield ${ }^{1,2, *}$, Martin K. S. Lilley ${ }^{2}$, Charles M. Bishop ${ }^{3}$, Peter Brown ${ }^{4}$, \\ Kostas A. Katselidis ${ }^{1,5}$, Panayotis Dimopoulos ${ }^{1}$, John D. Pantis ${ }^{6}$, Graeme C. Hays ${ }^{2}$ \\ ${ }^{1}$ Department of Environmental \& Natural Resources Management, University of Ioannina, G. Seferi 2, 30100 Agrinio, Greece \\ ${ }^{2}$ Department Biological Sciences, Institute of Environmental Sustainability, Swansea University, Singleton Park, \\ Swansea SA2 8PP, UK \\ ${ }^{3}$ School of Biological Sciences, University of Bangor, Wales, Deiniol Road, Bangor, Gwynedd LL57 2UW, UK \\ ${ }^{4}$ Navsys Ltd., Kirknewton, Edinburgh EH27 8DY, UK \\ ${ }^{5}$ National Marine Park of Zakynthos, 1 El. Venizelou Street, 29100 Zakynthos, Greece \\ ${ }^{6}$ Department of Ecology, School of Biology, UP Box 119, Aristotle University of Thessaloniki, 54006 Thessaloniki, Greece
}

\begin{abstract}
The implementation of appropriate protection measures for endangered species in protected areas requires knowledge of their fine-scale habitat use. In May and June of 2006 and 2007, we used GPS loggers (some linked to the Argos system) and a conventional Argos transmitter to track male and female loggerhead turtles Caretta caretta in the vicinity of the breeding area of Laganas Bay within the National Marine Park of Zakynthos, Greece. We obtained (1) 9681 useable locations (mean: 1383 locations ind ${ }^{-1}$; range: 519 to 2198 locations) from Tracktag GPS loggers attached to 7 females for a mean duration of $34 \mathrm{~d}$ (range: 17 to $52 \mathrm{~d}$ ); (2) 1245 useable locations (mean: 311 locations ind ${ }^{-1}$; range: 38 to 1110 locations) from 4 males fitted with Fastloc Argos tags for a mean duration of $29 \mathrm{~d}$ (range: 3 to $51 \mathrm{~d}$ ) and (3) 100 locations from 1 male fitted with a conventional Argos satellite tag tracked for $128 \mathrm{~d}$. GPS data indicated that before the onset of nesting, both males and females primarily used an area within $500 \mathrm{~m}$ of the shore along a core $9 \mathrm{~km}$ stretch of coastline, where existing protective legislation requires strengthening. Our observations suggest that a $76.7 \%$ female-biased operational sex ratio, measured previously from in-water surveys, may represent a realistic sex ratio estimate in the period before nesting starts. In the first month following the onset of nesting, female spatial distribution remained similar, whereas most males departed for distant areas presumably to forage. Our study provides quantitative evidence of the need to improve the management planning and conservation measures to protect sea turtles in a coastal breeding area, and new insights on male turtle migration.
\end{abstract}

KEY WORDS: Conservation management $\cdot$ Endangered species $\cdot$ Population density $\cdot$ Marine vertebrate $\cdot$ Migratory species $\cdot$ Multiple paternity $\cdot$ Wildlife telemetry

\section{INTRODUCTION}

Effective conservation management of wide-ranging marine vertebrates requires quantitative information at both local and regional levels (Hyrenbach et al. 2000). In recent decades, satellite telemetry has facilitated the tracking of wildlife movement over thousands of $\mathrm{km}$.
Invaluable information has been provided on migratory corridors and the essential resources that they link, such as reproductive and foraging grounds (Morreale et al. 1996, Sheppard et al. 2006, Rasmussen et al. 2007, Zbinden et al. 2008). While such corridors are rarely protected, partly due to the fact that they often traverse political borders, the prime resource sites they connect 
may meet 'siting' criteria for inclusion within national protected area management schemes (Gardenfors 2001, Campbell 2007, Lawton 2007, Wood \& Dragicevic 2007). To formulate effective protective zoning and associated conservation legislation and policies, objective and quantitative evidence is required with respect to habitat preferences of key species and core area use within such sites (Sutherland et al. 2004, Togridou et al. 2006). This is of particular consequence in coastal zones where increasing levels of human settlement, leisure and fishing activities may already be placing pressure on endangered species populations and the natural resources on which they depend (Martien et al. 1999, Zbinden et al. 2007a). However, conventional satellite transmitters provide only fairly coarse spatial resolution and are primarily useful in documenting broad-scale movements (Hays et al. 2001a). Recently, tracking units based on GPS technology have become available to wildlife researchers, with an accuracy of metres (Hulbert \& French 2001). For this reason, GPS technology is an increasingly important tool to quantitatively address the conservation management requirements of wide ranging terrestrial and marine species both within and between the reserves designated to protect them (Ryan et al. 2004, Douglas-Hamilton et al. 2005, Schofield et al. 2007).

For the globally endangered sea turtle species, much information is now available on the periodic broadscale movements of adult females as they migrate between nesting and foraging areas, which is usually derived from Argos satellite transmitters (e.g. Luschi et al. 2003, James et al. 2005b, Broderick et al. 2007, Zbinden et al. 2008). Habitat use within breeding and foraging areas has been inferred using mark-recapture, radio, sonic and/or satellite telemetry (van Dam \& Diez 1998, Hopkins-Murphy et al. 2003, Zbinden et al. 2007a), and more recently GPS units (Yasuda \& Arai 2005, Schofield et al. 2007). However, there remains a bias towards female-oriented research because they come ashore to nest, providing an easy opportunity to attach tracking equipment. At temperate breeding areas, satellite and sonic telemetry studies of female loggerheads indicate use of areas <15 m deep (Hopkins-Murphy et al. 2003, Zbinden et al. 2007a), and recent GPS tracking indicates possible use of areas as shallow as $<4 \mathrm{~m}$ (Schofield et al. 2007).

Compared to females, far less is known about male turtle movements (but see Limpus 1993, Plotkin et al. 1996, Hays et al. 2001b, James et al. 2005a, Shaver et al. 2005), due to the necessity, and difficulties, of in-water capture (Ehrhart \& Ogren 1999). Existing research indicates that males may occupy areas of up to $40 \mathrm{~m}$ depth at breeding grounds (Shaver et al. 2005) and, following a protracted mating period, appear to exhibit similar migration patterns to adult female conspecifics (for overview see Sakamoto et al. 1997, Godley et al. 2008). To objectively determine whether existing or suggested protection measures at local (i.e. within a national park or reserve), national and regional level is appropriate, high-resolution tracking of all segments of the population actively using the area is needed (Seminoff et al. 2002). Furthermore, in the Mediterranean, sea turtle foraging areas remain largely lacking in protective legislation (Zbinden et al. 2008), hence confirmation of the use of certain areas by both adult males and females following migration from breeding areas may provide evidence supporting the establishment of much needed protection sites.

The island of Zakynthos, Greece, hosts the largest known breeding population of loggerheads in the Mediterranean (Margaritoulis 2005). Several hundred loggerhead turtles enter Laganas Bay at the southern part of Zakynthos to breed from mid April onwards (Schofield et al. 2006), and female turtles generally nest from late May until early August, with an average of 1300 clutches per season (Margaritoulis 2005). Existing marine protection zones were delineated based on nesting beach locations and relative nesting densities (Arapis \& Margaritoulis 1996). Since the formation of the National Marine Park of Zakynthos (NMPZ) in 2000, regulation of recreational nearshore activities (particularly organised and incidental turtle watching activities) has been strengthened; however, for new legislation to be passed, accurate information on marine area use by adult male and female turtles is essential. During in-water surveys to assess turtle distribution and behaviour between 2003 and 2005 (Schofield et al. 2006, 2008), we noted a strong bias towards female sightings ( $\mathrm{n}=80$ male, $\mathrm{n}=1335$ female), and accredited this at the time to differential spatial use by males and females in Laganas Bay. Preliminary research using highly accurate GPS TrackTag loggers indicates that female turtles primarily utilise $18.5 \mathrm{~km}$ of nearshore coastline at seabed depths of $<5 \mathrm{~m}$ (or up to $1 \mathrm{~km}$ distance from shore; Schofield et al. 2007). However, it was not known whether males exhibit similar patterns.

The aim of our study was to investigate the fine scale movement of male and female loggerhead turtles Caretta caretta within a major breeding rookery using GPS tracking units. We also assess the departure of males from the breeding grounds and identify the location of distant post-breeding, presumably foraging, sites. We consider how our data might be used to contribute to sea turtle conservation measures, policies and legislation at a local and regional scale. At the local scale, we evaluate the status of protection measures in the NMPZ, while at the regional scale we contribute information for protection across international borders of male sea turtles through linking of breeding and foraging areas. 


\section{MATERIALS AND METHODS}

Study area. Laganas Bay is situated at the southeastern part of Zakynthos island, Greece $\left(37^{\circ} 43^{\prime} \mathrm{N}\right.$, $\left.20^{\circ} 52^{\prime} \mathrm{E}\right)$. The bay is generally shallow, reaching a depth of about $50 \mathrm{~m}$ and a marine area of $89.2 \mathrm{~km}^{2}$, which forms the Marine Protection Area of the NMPZ. Laganas Bay has a coastline of $27.8 \mathrm{~km}$ in length (Fig. 1). Within the bay are 6 discrete nesting beaches (Fig. 1) with a total length of $6.16 \mathrm{~km}$ (Margaritoulis 2005).

Tracking units and turtle capture technique. During 2006 and 2007, GPS tracking units were placed on adult male and female loggerheads; GPS transmitters were placed on males due to the low likelihood of resighting for unit retrieval (and hence the need to remotely relay data), while GPS loggers were placed on females, since units could be removed when individuals subsequently nested. In 2006 and 2007, TrackTag ${ }^{\mathrm{TM}}$ GPS loggers (Navsys, www.navsys.com) were deployed onto 4 and 5 adult female loggerhead turtles (curved carapace lengths 77 to $89 \mathrm{~cm}$ ), respectively. The units were attached during the pre-nesting period in May and removed in June (see Schofield et al. 2007 for detailed logger information). In 2 cases (one in each year), loggers malfunctioned due to deployment problems so that no data were collected. In 2007, 4 Fastloc GPS-Argos tags (Sirtrack, www.sirtrack.com) and 1 conventional Kiwisat 101 PTT Argos unit (Sirtrack) were deployed onto males (curved carapace lengths 79 to $91 \mathrm{~cm})$. The Fastloc GPS-Argos transmitters relayed

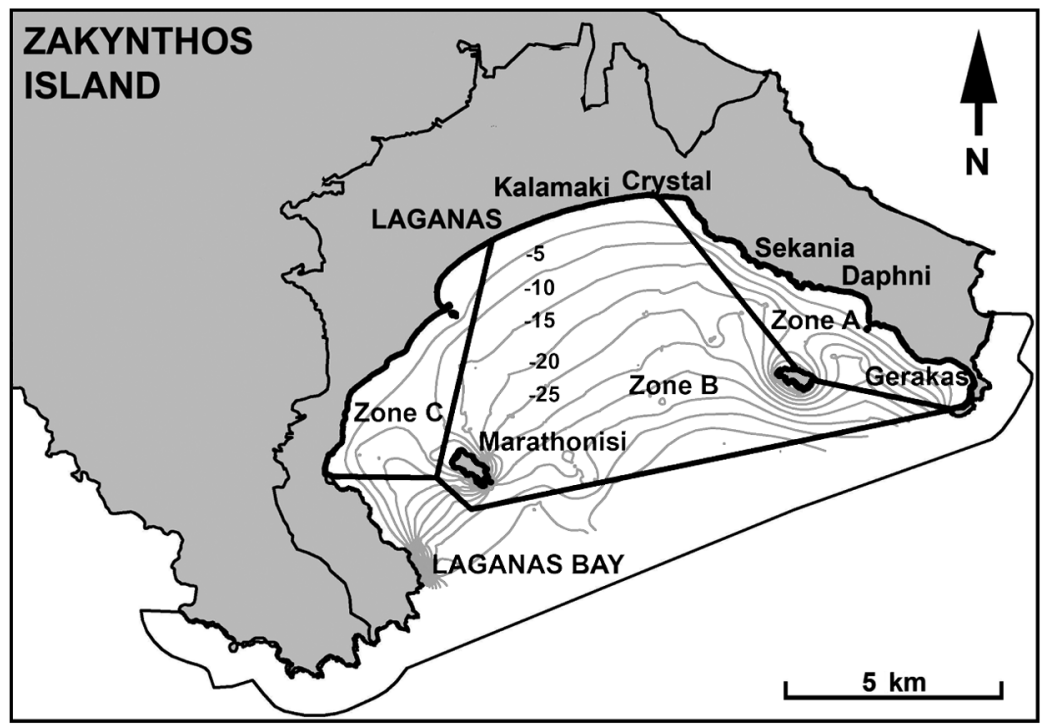

Fig. 1. Area of the National Marine Park of Zakynthos (NMPZ) encompassing the 6 loggerhead nesting beaches of Laganas Bay (Marathonisi, Kalamaki, Crystal, Sekania, Daphni, Gerakas). Bathymetry (isobars at $5 \mathrm{~m}$ sea depth intervals) and the 3 NMPZ protection zones are shown; Zone A (no boating activity), Zone $\mathrm{B}$ (boating speed up to $6 \mathrm{kn}$ permitted and no mooring), Zone $\mathrm{C}$ (boating up to $6 \mathrm{kn}$ permitted and mooring)
GPS information remotely via the Argos system. The Fastloc tags were on continuously but included a saltwater switch to suppress attempts to transmit or acquire data when the units were submerged. In addition, the Fastloc data was stored on-board, so that all the acquired Fastloc-GPS data could be downloaded directly to a computer in the event of instrument recovery. One coat of antifoulant was painted on all Sirtrack units.

Navsys estimates the accuracy of TrackTag locations to be around $30 \mathrm{~m}$ (2dRMS) for $95 \%$ of locations recorded using a horizontal and stationary receiver in the UK. Fastloc units have an accuracy of $55 \mathrm{~m}$ in $95 \%$ of locations recorded and $20 \mathrm{~m}$ in $50 \%$ of locations recorded (see www.sirtrack.com). The conventional Argos unit accuracy is categorised by location classes (LC): LC 3, LC 2, LC 1 or LC 0 locations, which are classified as within $150,>150$ to $350,>350$ to 1000 or $>1000 \mathrm{~m}$. Locations classified as Classes A and B have been ill defined, but probably indicate poor accuracy (particularly LC B) (Hays et al. 2001a).

A $4 \mathrm{~m}$ research boat was used to find turtles at water depths of 1 to $7 \mathrm{~m}$. Turtles were captured at random along the central $12 \mathrm{~km}$ stretch of coastal waters over submerged sandbanks only (for safety reasons) using the turtle-rodeo technique (Ehrhart \& Ogren 1999), and were swum into a semi-submerged wooden box attached to the side of the boat (Fig. 2a). Following capture, curved carapace length was measured and a GPS logger or transmitter was attached using a standard method previously employed with various transmitters/loggers (Hays et al. 2003). In brief, the carapace was cleaned and then the logger, embedded in quick setting 2-part epoxy resin (Powerfastners) with wooden baffles, was positioned at the anterior to help prevent impacts to the equipment (Fig. 2b,c). The reproductively active status of captured individuals was determined through in-water observation of courtship and mating activity. The attachment of all devices was conducted under licenses from the Greek Ministry of Agriculture. All GPS loggers and one GPS transmitter were retrieved from the animals by 1 of 2 methods: (1) using the rodeo capture technique or (2) by recovery on the beach immediately following nesting.

Data analysis. All GPS transmitter and logger locations were first plotted to allow a quick initial visual inspection. The data were filtered by (1) subjectively removing visually erroneous locations (i.e. on land or spatially different fixes to previous and successive fixes 
within the same timeframe), (2) using a maximum rate of travel of $5 \mathrm{~km} \mathrm{~h}^{-1}$ between successive locations (Hays et al. 2004), which was selected based on calculations from 3 or more consecutive fixes occurring at 10 to 20 min intervals, and (3) removing data from when the turtles were onshore (nesting and/or aborted nesting attempts). We then calculated the mean GPS location $\mathrm{h}^{-1}$ for each turtle (Tremblay et al. 2006). We calculated the daily mean location of each turtle from the hourly datasets, from which the daily distance from shore of different turtles was calculated. We divided the $27.8 \mathrm{~km}$ coastline of Laganas Bay into 3 equal sections of coastline, each $9 \mathrm{~km}$ long (the eastern, central and western sections), and used hourly datasets to determine general area use. Note that the eastern section of coastline falls in the highly protected noboating park zone, while the eastern and central sections fall in the low protected zones where boating is permitted. An estimate of migratory distance for the males was calculated by summing up distance travelled between daily locations. For the data from the conventional Argos PTT unit, locations were filtered using a maximum rate of travel of $5 \mathrm{~km} \mathrm{~h}^{-1}$ between successive locations (Hays et al. 2004).

In order to correlate male departure times with respect to the onset of nesting, information on the daily nest number in 2007 was obtained from the NMPZ for all beaches in Laganas Bay. The number of new nests from the previous night was assessed from tracks. The mean date of nesting for 2007, 3 July, was determined by:

$$
\text { Mean date of nesting }=\frac{\sum x f}{\sum f}
$$

where $x$ is the day of year (i.e. 1 January = Day 1 and 31 December $=$ Day 365) and $f$ is the number of nests.
The nesting 'peak' is the date on which the greatest number of nests was recorded (27 June, Day 178).

The mean date on which the transition between the pre-nesting (phase prior to the first nesting event) and internesting (phase between first and last nesting events) period occurred was calculated from the first nesting event for each female from the GPS datasets (Table 1). This was identified when locations were being consistently recorded at $30 \mathrm{~s}$ intervals for a minimum of $30 \mathrm{~min}$, indicating that the turtle was on land. If more than one nesting event was recorded in a $5 \mathrm{~d}$ period, the last event was selected as the successful event, with the preceding events being recorded as non-nesting emergences. Subsequent nesting events were also identified in 5 of the tracked turtles, and this information was used to calculate internesting intervals. For correlation with the dataset of the male that remained in the breeding area, we also separated the 2 periods by identifying the date from which nests were recorded daily thereafter. In 2006 and 2007, the first nest was laid on 29 May (Day 149) and 17 May (Day 137), respectively, with regular daily nesting being recorded from 29 May (Day 149) and 1 June (Day 152) onwards, respectively.

Nearshore surveys. For the current study, we revisited the in-water sea turtle distribution and behaviour datasets from 2003, when the most robust surveys were conducted by boat (Schofield et al. 2006, 2008). On 27 fair weather days from 14 April to 31 May 2003, daily line transects were made at seabed depths of 3,5 , 7 and $10 \mathrm{~m}$ (i.e. up to $1 \mathrm{~km}$ from shore) along a $5.5 \mathrm{~km}$ stretch of nearshore coastline within Laganas Bay (for map see Schofield et al. 2006). Boat surveys (405 km total distance, $137 \mathrm{~h}$ total duration) were conducted by 2 to 3 observers on a $4 \mathrm{~m}$ boat with an outboard engine. Sessions lasted an average of $5 \mathrm{~h}$ (minimum 4, maxi-

Table 1. GPS logger and transmitter locations acquired and those remaining after filtration. Dates given as dd/mm/yyyy. CCL: curved carapace length of turtle; CCW: curved carapace width of turtle. No. of operational days and mean points per day are highlighted in bold

\begin{tabular}{|c|c|c|c|c|c|c|c|c|c|c|c|}
\hline \multirow{2}{*}{$\begin{array}{l}\text { Year } \\
2006\end{array}$} & \multirow{2}{*}{$\begin{array}{l}\text { Turtle ID } \\
\text { Female_1 }\end{array}$} & \multirow{2}{*}{$\begin{array}{l}\text { Device } \\
\text { TrackTag GPS }\end{array}$} & \multicolumn{2}{|c|}{$\begin{array}{c}\text { CCL CCW } \\
(\mathrm{cm})\end{array}$} & \multirow{2}{*}{$\begin{array}{l}\text { Date GPS } \\
\text { attached }\end{array}$} & \multirow{2}{*}{$\begin{array}{l}\begin{array}{l}\text { Date GPS } \\
\text { stopped }\end{array} \\
6 / 6 / 2006\end{array}$} & \multirow{2}{*}{$\begin{array}{l}\text { Date of } \\
\text { first nesting }\end{array}$} & \multirow[t]{2}{*}{$\begin{array}{l}\text { Date of } \\
\text { departure }\end{array}$} & \multirow{2}{*}{$\begin{array}{c}\begin{array}{c}\text { No. days } \\
\text { operational }\end{array} \\
\mathbf{1 7}\end{array}$} & \multicolumn{2}{|c|}{$\begin{array}{l}\text { Post-filtering locations } \\
\text { Total Mean } \mathrm{d}^{-1}\end{array}$} \\
\hline & & & 81 & 73.5 & & & & & & 519 & 31 \\
\hline 2006 & Female_2 & TrackTag GPS & 89 & 76 & $23 / 5 / 2006$ & $26 / 6 / 2006$ & $25 / 6 / 2006$ & & 31 & 2198 & 69 \\
\hline 2006 & Female_3 & TrackTag GPS & 87 & 72 & $24 / 5 / 2006$ & $18 / 6 / 2006$ & $7 / 6 / 2006$ & & 25 & 818 & 33 \\
\hline 2007 & Female_4 & TrackTag GPS & 83 & 75 & $4 / 5 / 2007$ & $25 / 6 / 2007$ & $5 / 6 / 2007$ & & 52 & 2081 & 25 \\
\hline 2007 & Female_5 & TrackTag GPS & 84 & 77 & $8 / 5 / 2007$ & $11 / 6 / 2007$ & $3 / 6 / 2007$ & & 34 & 909 & 27 \\
\hline 2007 & Female_6 & TrackTag GPS & 81 & 74 & $9 / 5 / 2007$ & $26 / 6 / 2007$ & $23 / 5 / 2007$ & & 48 & 1779 & 37 \\
\hline 2007 & Female_7 & TrackTag GPS & 77 & 66 & $11 / 5 / 2007$ & $12 / 6 / 2007$ & $21 / 5 / 2007$ & & 35 & 1377 & 39 \\
\hline 2007 & Male_1 & Sirtrack GPS & 81 & 72 & $8 / 5 / 2007$ & $26 / 6 / 2007$ & & $\mathrm{n} / \mathrm{a}$ & 49 & 1110 & 23 \\
\hline 2007 & Male_2 & Sirtrack GPS & 91 & 81 & $10 / 5 / 2007$ & $30 / 6 / 2007$ & & $20 / 5 / 2007$ & 51 & 53 & 1 \\
\hline 2007 & Male_3 & Sirtrack GPS & 81 & 74 & $14 / 5 / 2007$ & $17 / 5 / 2007$ & & $14 / 5 / 2007$ & 3 & 38 & 13 \\
\hline 2007 & Male_4 & Sirtrack GPS & 79 & 70 & $10 / 5 / 2007$ & $25 / 5 / 2007$ & & $22 / 5 / 2007$ & 15 & 44 & 1 \\
\hline \multirow[t]{2}{*}{2007} & Male_5 & Sirtrack satellite & 90 & 83 & $7 / 5 / 2007$ & $12 / 9 / 2007$ & & $23 / 5 / 2007$ & 128 & 100 & 0.8 \\
\hline & & & & & Total & & & & 488 & 11026 & 22.5 \\
\hline
\end{tabular}



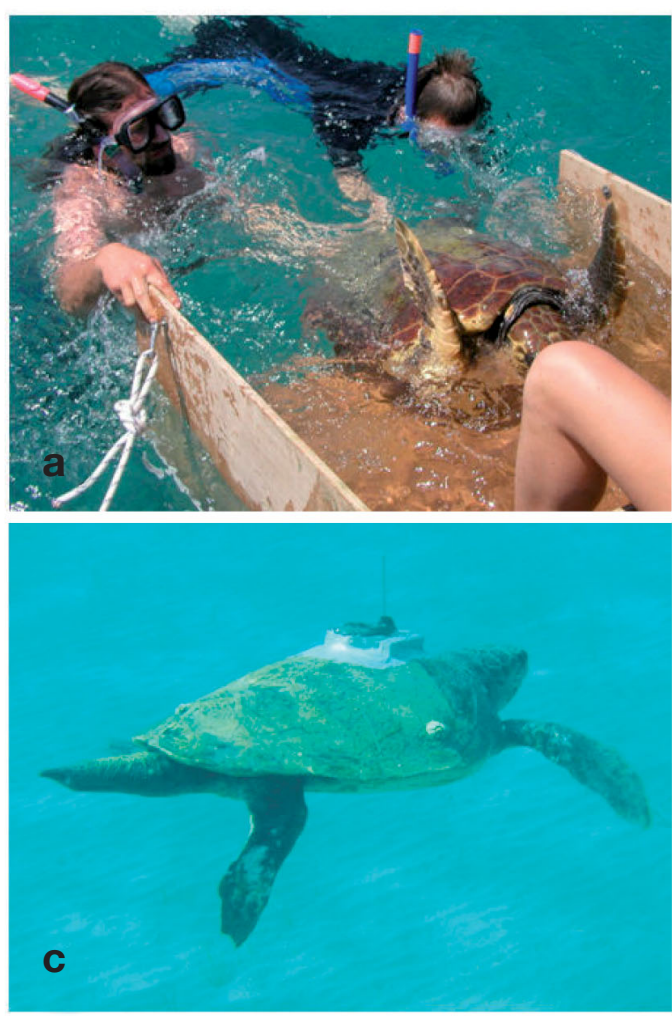

mum $7 \mathrm{~h}$ ) at a maximum boat speed of 4 knots. The survey period covered a range of daylight hours between 09:30 and 19:30 h. GPS locations of turtle sightings were recorded using Garmin E-Trex hand-held units and still photographs were taken underwater when snorkelling at a distance of 2 to $7 \mathrm{~m}$ from the target animal, using an Olympus Digital 500 (5.0 megapixel) camera with underwater housing. Animal gender was determined based on tail-length dimorphism (Casale et al. 2005) and presence/absence of external identification-tags (only females are tagged).

We used the natural scalation patterns on the lateral facial region to identify individual turtles with high accuracy (see Schofield et al. 2008).

\section{RESULTS}

\section{Tracking data}

Excluding deployment and retrieval days, we tracked 3 female turtles equipped with TrackTag GPS loggers in 2006 and 2007 for a mean 34 d each (range 17 to 52 d). The 4 males equipped with Fastloc GPSArgos transmitters were tracked for a mean $29 \mathrm{~d}$ each (range 3 to $51 \mathrm{~d}$ ). The 1 male equipped with a conventional Argos transmitter was tracked for $128 \mathrm{~d}$ (Table 1). The volume of useable locations obtained from the different devices (TrackTag GPS loggers,

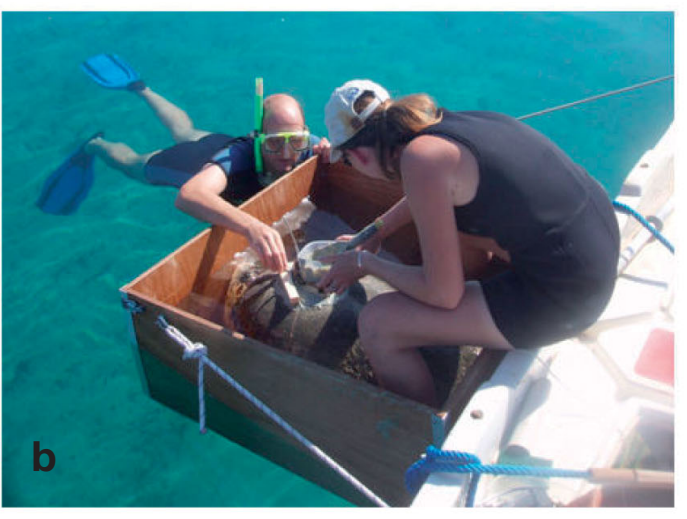

Fig. 2. Caretta caretta. Adult male loggerhead sea turtle (a) at capture; (b) during Sirtrack Fastloc GPS-Argos transmitter attachment and (c) immediately following release (photos by Mike and Jeanette Sheldon)

unretrieved Fastloc GPS-Argos transmitters, retrieved Fastloc GPS-Argos transmitter and conventional Argos satellite transmitter) are presented in Table 1. The retrieved TrackTag loggers and Fastloc transmitter provided a much greater volume of data compared to that relayed via Argos. As expected, given their greater accuracy, all GPS units provided very detailed information on sea turtle area use, in contrast to the conventional Argos unit from which only the general location of the turtle could be inferred (Fig. 3).

\section{Male and female area use in the breeding area}

The data from the GPS units (loggers and transmitters) indicated that both male and female turtles primarily used the marine area close to shore (from hourly positional datasets) (Fig. 3a \& video animation in electronic supplement at www.int-res.com/articles/ suppl/n010p191_app/). Before and after the onset of nesting, $82 \%$ of all 7 female GPS locations in Laganas Bay occurred within $500 \mathrm{~m}$ of the shore (Fig. 4a) (approx. depth $<5 \mathrm{~m}$ ). In the pre-nesting period, 92\% of all 4 male GPS locations also occurred within $500 \mathrm{~m}$ of the shore in Laganas Bay (Fig. 4b).

The GPS units not only indicated this nearshore preference, but also that the tracked males and females appear to prefer certain stretches of coastline within Laganas Bay. We found that, before the onset of nest- 

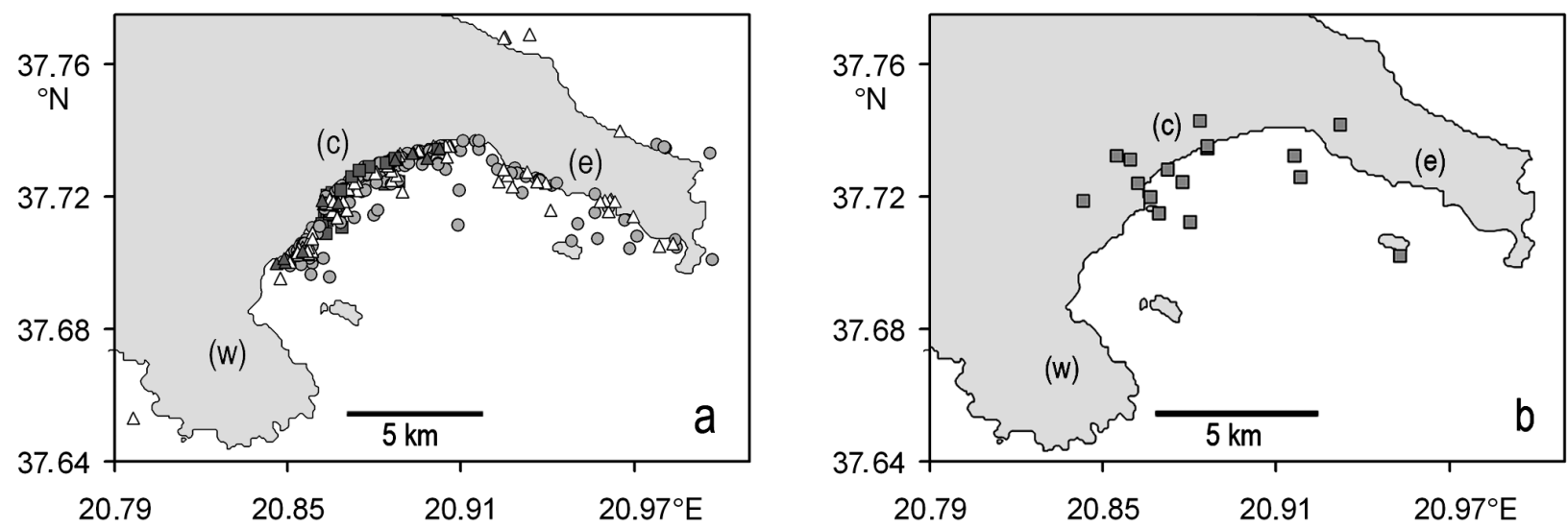

Fig. 3. Caretta caretta. Daily mean (a) GPS locations for males ( $=4,72$ locations, squares) and females (2006: $\mathrm{n}=3$, 109 locations, triangles; 2007: $\mathrm{n}=4,124$ locations, circles) in Laganas Bay and (b) male Argos locations ( $\mathrm{n}=1,16$ locations). We considered Argos fixes falling on land as belonging to the closest point off the coast. Bay divisions: (w) western (c) central, (e) eastern

ing, $100 \%$ of male GPS locations and $77 \%$ of female GPS locations occurred along the central section of coastline. Only one GPS-tracked male remained in Laganas Bay following the onset of the nesting season and appeared to restrict all its activity to the central section of coastline before and after the onset of nesting. Of the 7 tracked females, activity was confined within Laganas Bay before the onset of nesting (99\% of GPS locations), with some movement out of Laganas Bay occurring after the nesting season had started in June ( $79 \%$ of GPS locations in Laganas Bay).

After the onset of nesting, females continued to preferentially frequent the central section of coastline ( $54 \%$ of GPS locations). Before and after the onset of nesting, $21 \%$ of female GPS locations occurred along the eastern section of coastline (containing 3 nesting beaches together representing $70 \%$ of rookery nesting effort), which appeared to be associated with nesting activity, with turtles in general moving to this section of coastline 3 to $5 \mathrm{~d}$ before nesting. Just $0.2 \%$ of female GPS locations occurred along the western section of the coastline.

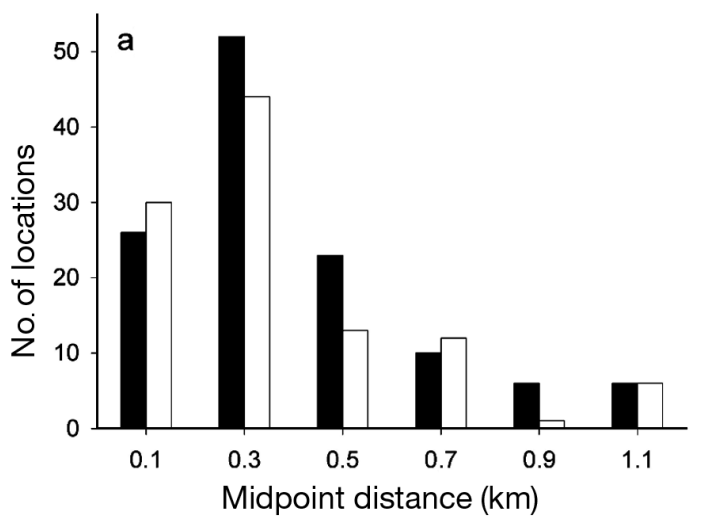

\section{Female movement in the vicinity of the breeding area}

Of the 7 females tracked using GPS loggers, 4 remained in Laganas Bay before and after the onset of nesting. Three turtles exited Laganas Bay on 6 occasions. In 2006, one turtle exited Laganas Bay on 2 occasions, frequenting the island's west coast for one day during the pre-nesting period and the east coast for $4 \mathrm{~d}$ following the first nesting event. In 2007, 1 turtle exited Laganas Bay on one occasion during the internesting period and occupied the east coast for $4 \mathrm{~d}$. One turtle exited Laganas Bay on 3 occasions prior to the first nesting and swam to the east coast for $1 \mathrm{~d}$ on each occasion. The day following the first nesting (indicated by the GPS data), the same turtle travelled $96 \mathrm{~km}$ to Kyparissia Bay in the Peloponnese over a $15 \mathrm{~d}$ period (Fig. 5); travelling for $4 \mathrm{~d}$ directly to the Peloponnese, remaining there for $8 \mathrm{~d}$ and returning over $3 \mathrm{~d}$. The turtle nested again on Zakynthos 5 d later, with an internesting interval of $20 \mathrm{~d}$. It is unlikely that the turtle nested when in Kyparissia, as no locations were continuously recorded at $30 \mathrm{~s}$ intervals to indicate the

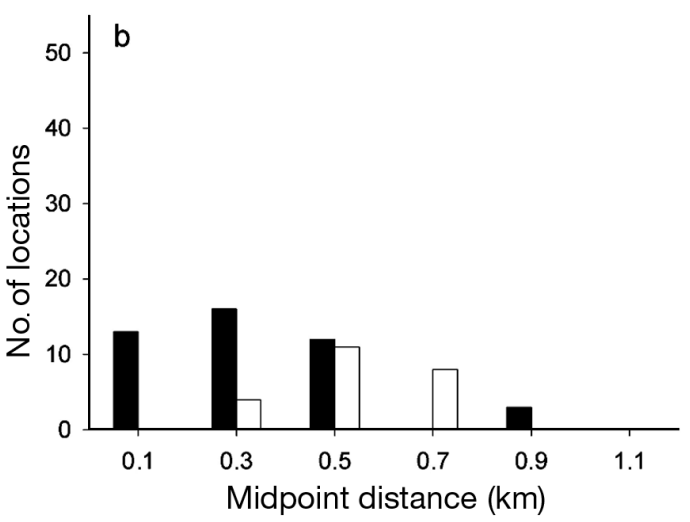

Fig. 4. Caretta caretta. Distance from shore before (black bars) and after (white bars) the onset of the nesting season for (a) females $(n=7)$ and (b) males ( $=4$ before and $n=1$ after) obtained from hourly positional datasets 


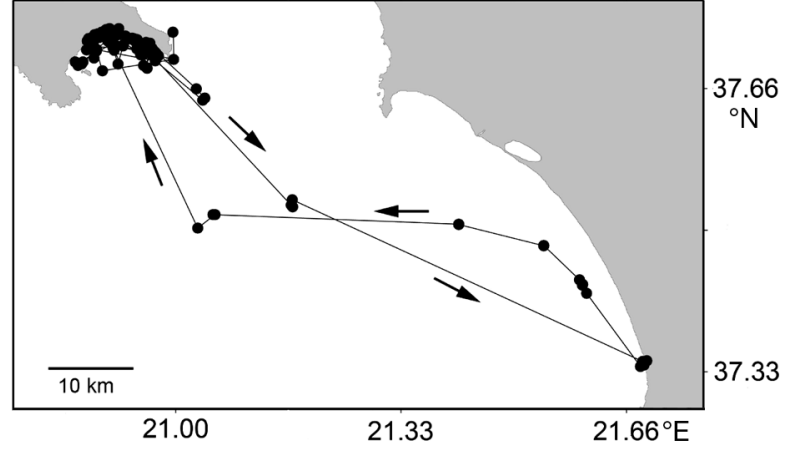

Fig. 5. Caretta caretta. Internesting migration from Zakynthos to the Peloponnese by 1 female during 2007

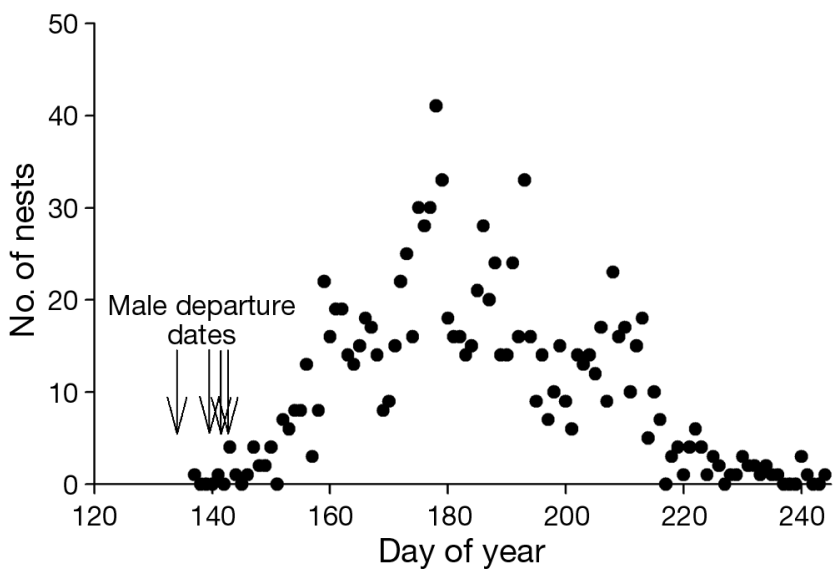

Fig. 6. Caretta caretta. Number of nests each day of year 2007. Days of departure of the 4 tracked male turtles are indicated with arrows (nesting data obtained from NMPZ archives) turtle was out of the water, and we also documented a mean internesting interval of $17 \mathrm{~d}(\mathrm{SD} \pm 3.3)$ in 5 of the tracked turtles.

\section{Male movement following the onset of the nesting season}

Males departed from the breeding grounds of Laganas Bay between 14 and 23 May (Table 1), which averaged $3 \mathrm{~d}$ after the first recorded nest (17 May, Day 137), $12 \mathrm{~d}$ before the start of regular nesting activity (1 June, Day 152), 38 d before the nesting peak (27 June, Day 178) and $44 \mathrm{~d}$ before the mean date of peak nesting (3 July, Day 183) (Fig. 6).

Four of the males departed in different directions; 2 departed in a south-easterly direction, one in a southwesterly direction and one in a north-westerly direction (Fig. 7a). One male remained in Laganas Bay and was last sighted on 27 August (when the Fastloc GPS-Argos transmitter was retrieved), still inhabiting the same nearshore section.

Two males were tracked to their presumed foraging areas (Fig. 7b). The male with the Fastloc GPS-Argos transmitter swam to a foraging area between the islands of Olib and Silba in Croatia, $721 \mathrm{~km}$ north of the nesting area. It travelled a total distance of $762 \mathrm{~km}$ over $21 \mathrm{~d}$ and was recorded to arrive at the presumed foraging grounds on 12 June, remaining there until 30 June when transmissions terminated. The male equipped with the conventional Argos transmitter swam to a foraging area in the Bay of Izmir in Turkey, $597 \mathrm{~km}$ north east of the nesting area. The turtle travelled a
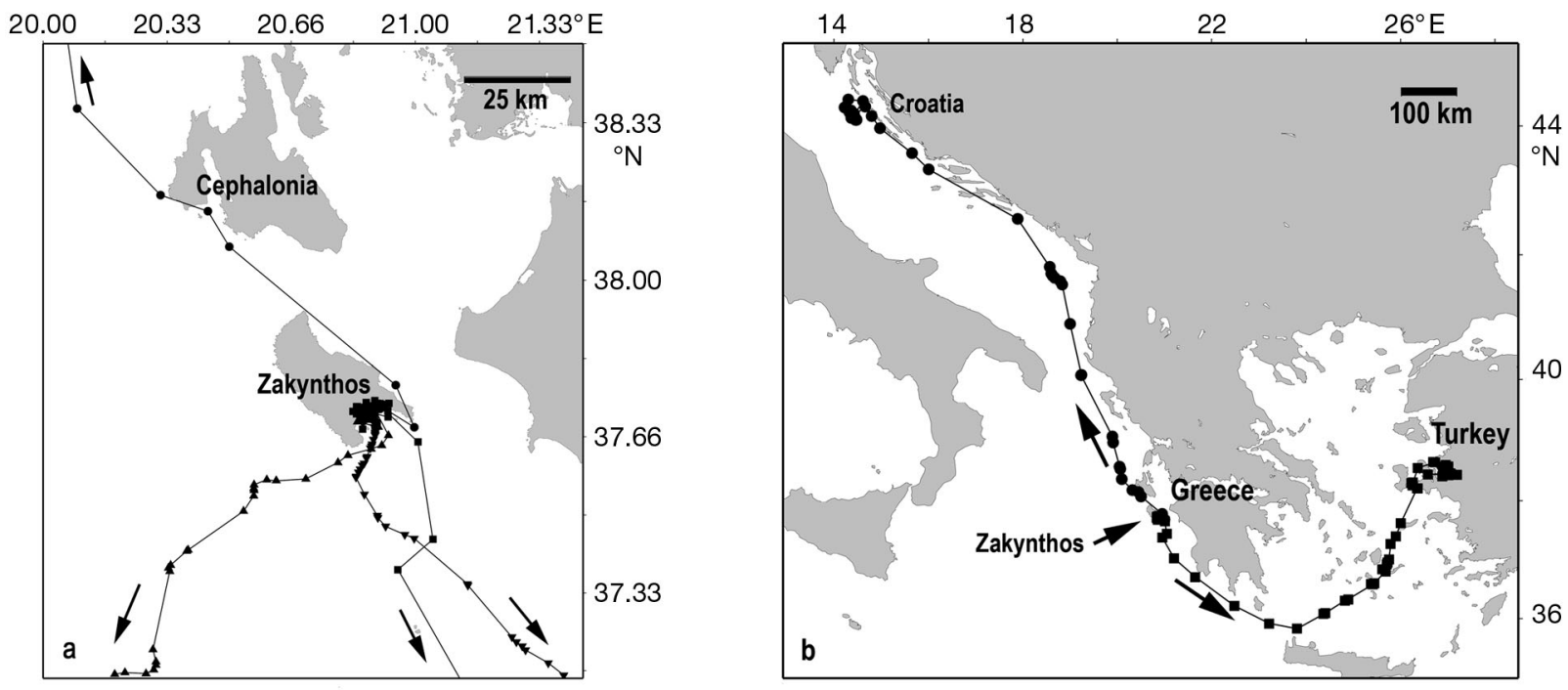

Fig. 7. (a) Disparate departure directions of the 4 males that migrated away from Zakynthos. (b) Long distance migration of 2 male turtles from the breeding area of Zakynthos; 1 GPS transmitter track to the islands of Olib and Silba in Croatia and 1 satellite transmitter track to the Bay of Izmir in Turkey 
total distance of $927 \mathrm{~km}$ (calculated from daily mean locations) to reach the presumed foraging area over an $18 \mathrm{~d}$ period, was recorded to arrive on 10 June and was still transmitting from the same vicinity on 12 September.

Interestingly, the male that remained in Laganas Bay changed its spatial area use in the periods before and after the onset of nesting activity from mainly within $500 \mathrm{~m}$ to more than $500 \mathrm{~m}$ from shore (Fig. 4b).

\section{Population parameters}

In the current study, we combine the results of the in-water surveys with turtle GPS locations information to calculate an operational sex ratio for the breeding area. We crudely estimated the mean female seasonal breeding population size to be 463 individuals by dividing the mean number of nests recorded between 1984 and 2002 (1293.7 nests; Margaritoulis 2005) with an estimated mean clutch frequency of 3 (based on information from Jensen et al. 2006, Zbinden et al. 2007a).

In 2003, photographic records were collected from a total of 460 loggerhead sightings during 27 surveys in April and May. From these records, we identified 38 unique males and 127 unique females, with an average resighting rate of 3 times per individual across surveys. From this information, we calculated a $76.7 \%$ female bias (1 male to 3.3 females) in the operational sex ratio. We also recorded the average sex ratio in each field survey and found a significant temporal change across the survey period, from $66.7 \%$ male bias ( 2 males to 1 female) in April to a $90 \%$ female bias (1 male to 9 females $)$ in late May $\left(F_{1,22}=71.3, r^{2}=0.75, p<0.001\right)$ (Fig. 8).

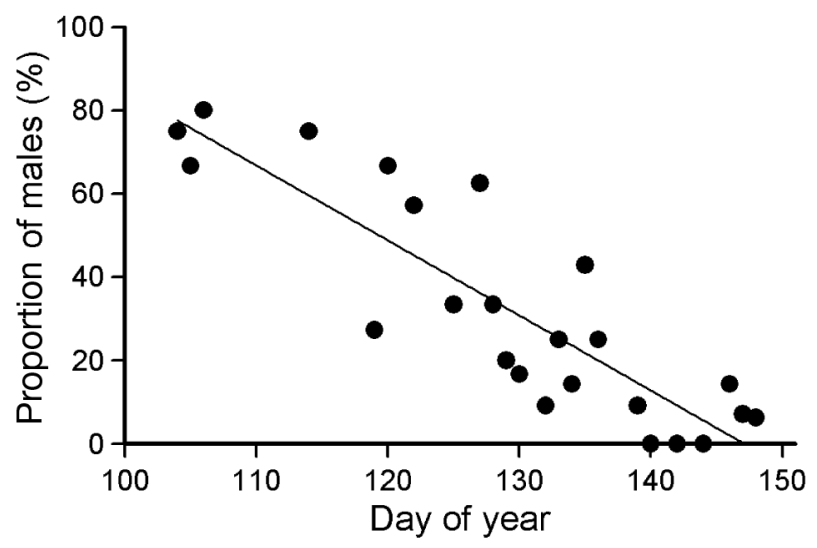

Fig. 8. Caretta caretta. Proportion of males present in the nearshore waters of Laganas Bay, showing a significant decline between 14 April and 31 May in $2003\left(F_{1,22}=71.3, r^{2}=\right.$ $0.75, \mathrm{p}<0.001)$

\section{DISCUSSION}

The fine-scale movements recorded for both male and female loggerhead turtles in the present study provide information on critical habitat use to guide management decisions fundamental to their conservation. Our data strongly suggest that, before the onset of nesting, both males and females use the same nearshore area, along a specific $9 \mathrm{~km}$ stretch of coastline and primarily within $500 \mathrm{~m}$ of shore (or within $5 \mathrm{~m}$ sea depths) in Laganas Bay. This supports previous observations that females use sea depths up to $15 \mathrm{~m}$ when in the breeding area (Hopkins-Murphy et al. 2003); however, our results indicate a much narrower area use by males than the previously recorded sea depths of up to $40 \mathrm{~m}$ (Shaver et al. 2005). One of the tracked males remained in the breeding area, with a noticeable shift in sea depth use to deeper water following the onset of nesting. This shift may have reflected a change in the status of a resident, i.e. from breeding to foraging, and may explain the greater depth range recorded for males in other breeding areas (see Shaver et al. 2005).

Our observations suggest that it is unlikely that females are successfully using the nearshore habitat as a refuge from males following mating (Booth \& Peters 1972, Whittow \& Balazs 1982). For example, females maintained the same pattern of nearshore habitat use in the first month following the onset of nesting, despite the fact that most males had migrated out of the breeding area by this time. Males may be found close to shore because they follow the females to maximise their mating opportunities. By restricting their area use, females may conserve energy expenditure during the reproductive season, when they may lay several clutches over several months (Hays et al. 1999, Wallace et al. 2005). Furthermore, turtles utilising the nearshore area of Laganas Bay have been found to experience water temperatures around $5^{\circ} \mathrm{C}$ above that in waters $>10 \mathrm{~m}$ depth (Schofield et al. 2009), which would decrease the duration between nesting events (Sato et al. 1998, Hays et al. 2002), thereby allowing a greater number of clutches to be laid when incubation conditions are optimal. Future studies might examine the behaviour of females later in the season to see if their interesting behaviour changes, for example with seasonally increasing water temperatures (Hays et al. 2002).

In 2006, one of the 3 tracked female turtles utilised waters outside of Laganas Bay (Schofield et al. 2007). The behaviour of this individual was not discussed due to the small sample size and the probability of this being anomalous for this population (see Zbinden et al. 2007a). However, the results of the 2006 and 2007 tracking data combined indicated that several of the 
tracked females moved at spatial scales beyond the main breeding area, which is consistent with previous suggestions that loggerheads may show poorer beach fidelity (Stoneburner 1982, Hays \& Sutherland 1991, Katselidis et al. 2004) than some other sea turtle species (Mortimer \& Portier 1989). The discrepancy in observations between Zbinden et al. (2007a) and our study, both in the same breeding area, may be attributed to the former recording movement in late June to August and the latter recording movement in May to late June, possibly indicating a change in behavioural patterns across the nesting period. The level of internesting movement may depend on the habitat needs of each species, such as foraging in leatherbacks (Georges et al. 2007) or possibly prospecting alternative nesting sites in loggerheads. This suggestion is supported by the fact that nesting activity does occur on the east coast of Zakynthos and Peloponnese where the turtles were recorded in our study. If these broad-scale movements occur regularly within the population, then current protective measures of the Zakynthos breeding area may require re-evaluation.

The use of GPS tracking in the present study defined the fine-scale habitat use by both males and females of the sea turtle breeding population and, therefore, the critical site at which heightened protection measures are required (Sutherland et al. 2004, Wood \& Dragicevic 2007). Our research was conducted in collaboration with the NMPZ to evaluate the effectiveness of existing protective zoning. Of management interest, GPS tracking of females in 2006 and 2007 indicated preferential nearshore area use outside of the core marine protected area, with similar patterns being recorded in tracked males. Our findings support the experimental introduction of the national park 'ecotourism zone' in 2006 to reduce disturbance to turtles through stricter boating regulations (Lusseau 2004) and expansion to include the prime section of coastline used by both sexes. However, governmental legislative action is required to reform existing zones, which is difficult to secure (Togridou et al. 2006, Campbell 2007, Lawton 2007). Our study also indicated the possible presence of resident turtles, hence research to determine winter area use around Zakynthos is important to improve protection measures, particularly with respect to the fishery industry bycatch (Martien et al. 1999). GPS tracking facilitates the fine-scale analysis of wildlife movement patterns and we strongly recommend its use in the delineation of protection zones to ensure that the habitat requirements of the species in question are met (Martien et al. 1999, Sutherland et al. 2004, James et al. 2005b).

Establishing the number of adult males and females is important, as empirical evidence for highly skewed female adult sex ratios may necessitate an increased conservation focus on males. Furthermore, climate change may impact turtle population dynamics, hence an understanding of sex ratios at different life stages is vital to ensure effective protection. At the Zakynthos rookery, we inferred a highly female-biased adult sex ratio using our photo-identification and GPS tracking information. The GPS tracks from our 11 male and female turtles indicated that $100 \%$ of male and $77 \%$ of female hourly locations occurred along the central $9 \mathrm{~km}$ of coastline during May. The consistency of nearshore use by tracked individuals in this study strongly suggests that this is a general feature of the population as a whole, therefore the Zakynthos operational sex ratio recorded in 2003 may be representative of the population. However, as with many biotelemetry studies, our sample sizes were fairly small and further tracking with larger sample sizes would clearly be useful. To obtain a preliminary estimate of population size, we crudely combined the 2003 sex ratios with the mean female operational population size. We predicted an operational population size of about 593 individuals: 130 males and 463 females. This calculation clearly contains a number of assumptionsfurther work is needed to refine estimates of relative males and female numbers as well as to establish the variance of these estimates.

Highly skewed female sex ratios of 60 to $99 \%$ have already been documented for loggerhead hatchlings in the Mediterranean (see Zbinden et al. 2007b) and other populations around the world (Mrosovsky \& Provancha 1989, Marcovaldi et al. 1997). Studies of juveniles indicate that skewed ratios may be balanced by males originating from elsewhere (Henwood 1987), though this may be a result of sex-related dispersal (Casale et al. 2006). Estimates of total population numbers and sex ratios depend on recruitment rates and the return rates of both males and females; females are believed to return biannually (Hays \& Sutherland 1991) and data from Australia suggest annual return rates in males (Chaloupka \& Limpus 2001). If this is the case, an $85 \%$ female bias may exist in the total adult population, which is similar to the $75 \%$ female bias in hatchling sex ratios on Zakynthos predicted by Zbinden et al. (2007b). However, robust measurements of remigration intervals for both males and females from a single population are scant, and this topic needs further study. If the difference in remigration intervals between males and females is even more marked than the 1 and $2 \mathrm{yr}$, respectively, that we have assumed, then the consequences are that the female bias in the adult sex ratio may be even more extreme than $85 \%$. Laganas Bay is not thought to contain large numbers of juvenile turtles. Certainly no small juveniles were seen during surveys. In theory, very large juveniles might be assigned as females, but the lack of smaller juve- 
niles suggests that this possibility is unlikely and therefore would not impact our conclusions in any important way.

We found that sea turtle density in the breeding area may be high, since our GPS data show that sea turtles primarily aggregate along $9 \mathrm{~km}^{2}$ (9 km long by $1 \mathrm{~km}$ out to sea) of coastline, rather than uniformly using the $89 \mathrm{~km}^{2}$ area of Laganas Bay. Based on our preliminary population estimate we calculated that, if sea turtle densities were uniform across Laganas Bay, there would be 5.3 ind. $\mathrm{km}^{-2}$. However, our GPS data suggested that, if $100 \%$ males and $77 \%$ females utilise $9 \mathrm{~km}^{2}$ nearshore area during May, we may have densities of 54 ind. $\mathrm{km}^{-2}$. Hence, this high use area should be the first priority for the management plan and legislation of the NMPZ. It should be noted that, for the purposes of these calculations, we used a clutch frequency of 3; however, this number is highly variable within loggerhead populations and requires confirmation (Dodd 1988). Estimating the number of turtles from the total number of clutches laid each year is crucially dependent on the estimate used for the mean number of clutches per individual. Establishing the number of adult males and females is important, as empirical evidence for highly skewed female adult sex ratios may necessitate an increased conservation focus on males. However, estimates of mean clutch frequency for sea turtles are problematic because of the logistic difficulties of observing females every time they nest. Hence, estimates of mean clutch frequency may need to be refined in the future as better data become available using new methods (e.g. Cronin \& McConnell 2008). The high density of turtles at Zakynthos may explain the unusually high multiple paternity recorded at the Zakynthos rookery (Zbinden et al. 2007c) despite it being a small loggerhead population relative to other rookeries exhibiting high levels of multiple paternity (Jensen et al. 2006, Lee 2008).

In support of the literature, we observed a male bias in the adult population at the start of the nesting season, yet most tracked males departed prior to the onset of nesting (Plotkin et al. 1996, Godley et al. 2002, James et al. 2005a). Both males and females undertake long migrations to breeding areas. Female turtles only need to mate once as they have the capacity to store sperm to fertilise subsequent clutches and so may resist multiple mating (Booth \& Peters 1972, Lee \& Hays 2004). Therefore, there is a trade-off for male turtles when away from the foraging area; to maximise paternity rates, they must arrive at the breeding area early enough to mate with unmated females, but not so early that they waste energy waiting for females to arrive. Males that remain at the breeding ground all year would save on the energetic cost of migration and have the potential to mate with more females, espe- cially in populations where female arrival is variable. While some individuals may forage year-round on Zakynthos, prey availability may not be adequate to sustain the population, resulting in different adult dispersal strategies as indicated by Shaver et al. (2005), with most males migrating out of the breeding area prior to the onset of nesting. Presumably, these males were departing from the breeding area when most females had mated and were no longer receptive (Plotkin et al. 1996, Hays et al. 2001b, Godley et al. 2002, James et al. 2005b).

Adult male turtles monitored by satellite have been recorded to travel large distances from breeding grounds (Sakamoto et al. 1997, Hays et al. 2001b, James et al. 2005a). One of the few studies to follow both sexes tracked adult leatherbacks in the North Atlantic, where similar long-distance movements for the sexes were seen (James et al. 2005b). Our results suggest that males have broadly similar dispersal and migratory patterns to those recorded in post-nesting females (Zbinden et al. 2008), with disparate distant (presumed foraging) grounds. Two of the males in our study were tracked to distant presumed foraging areas in Turkey and Croatia, identified due to the tracking locations being concentrated in one area. Following the widely held paradigm for the life history of loggerhead turtles, we assume these distant areas were foraging and/or overwintering areas (see Lohmann et al. 2008). By combining tracking data of sex and age classes with local empirical studies it may be possible to identify other foraging sites in need of national and trans-boundary conservation management action (Gardenfors 2001, Campbell 2007, Wood \& Dragicevic 2007).

Our study supports the value of GPS tracking for the understanding of spatial area use of marine vertebrates such as sea turtles at both local and regional scales. At the local scale, GPS tracking contributes to the evaluation of conservation measures, policies and legislation, while at the large scale, it can be applied to create integrated networks of protected areas encompassing breeding, migratory and foraging areas at national, trans-boundary and global levels. Our study indicated that, while retrievable GPS units produce a much larger volume of data, GPS transmitters provide the opportunity to track the fine-scale movement of more elusive components of the population (i.e. males) within the protected area and at postmigratory foraging grounds. This is of particular importance because of the low male sex ratios recorded in the Zakynthos population, which appears to continue throughout development. In conclusion, fine-scale GPS tracking of wildlife movement patterns may contribute towards enhancing national and international efforts to identify, delineate and develop new and effective protected areas. 
Acknowledgements. The authors thank the National Marine Park of Zakynthos (NMPZ) and Greek Ministry of Agriculture for permission to conduct this research. Financial and logistical support was provided by the Peoples Trust for Endangered Species, the British Chelonia Group, TrackTagConservation management, Endangered species, Population density, Marine vertebrate, Migratory species, Multiple paternity, Wildlife telemetry ${ }^{\mathrm{TM}}$, NERC Connect B Grant NERC/D/S/ 1999/00078 (award to C.M.B.), Swansea University and the NMPZ. We thank M. Baker, K. Gounelis, K. Katselidis, N. Margaris, G. Mitrouskas and M., J. and H. Sheldon for inwater capture assistance. We thank NMPZ and Archelon personnel for logger retrieval assistance: T. Lee, I. Palomares, V. Petta-Bika, D. E. Marcon, M. Barrett, P. Bradshaw, C. Dean, B. Gill, A. Hogg, D. Oakely, E. Ransome, B. van Divendyk, N. Walters and J. Zbinden. We acknowledge use of the Maptool program (www.seaturtle.org).

\section{LITERATURE CITED}

Arapis T, Margaritoulis D (1996) Sea turtle conservation and sustainable tourism for the proposed marine park on Zakynthos island, Greece. Coastal Management \& Habitat Conservation EUCC, Leiden, p 25-28

Booth J, Peters JA (1972) Behavioural studies on the green turtle (Chelonia mydas) in the sea. Anim Behav 20:808-812

Broderick AC, Coyne MS, Fuller WJ, Glen F, Godley BJ (2007) Fidelity and over-wintering of sea turtles. Proc R Soc Lond B Biol Sci 274:1533-1538

Campbell LM (2007) Local conservation practice and global discourse: A political ecology of sea turtle conservation. Ann Assoc Am Geogr 97:313-334

Casale P, Freggi D, Basso R, Argano R (2005) Size at male maturity, sexing methods and adult sex ratio in loggerhead turtles (Caretta caretta) from Italian waters investigated through tail measurements. J Herpetol 15:145-148

Casale P, Lazar B, Pont S, Tomas J and others (2006) Sex ratios of juvenile loggerhead sea turtles Caretta caretta in the Mediterranean. Mar Ecol Prog Ser 324:281-285

> Chaloupka M, Limpus CJ (2001) Trends in the abundance of sea turtles resident in southern Great Barrier Reef waters. Biol Conserv 102:235-249

Cronin MA, McConnell BJ (2008) SMS seal: A new technique to measure haul-out behaviour in marine vertebrates. J Exp Mar Biol Ecol 362:43-48

Dodd CK (1988) Synopsis of the biological data on the loggerhead sea turtle Caretta caretta (Linnaeus 1758), US Fish and Wildlife Service

Douglas-Hamilton I, Krink T, Vollrath F (2005) Movements and corridors of African elephants in relation to protected areas. Naturwissenschaften 92:158-163

Ehrhart LM, Ogren LH (1999) Studies in foraging habitats: capturing and handling turtles. In: Eckert KL, Bjorndal KA, Abreu-Grobois FA, Donnelly M (eds) Research and management techniques for the conservation of sea turtles. IUCN/SSC Marine Turtle Specialist Group Publication $4, \mathrm{p} 1-4$

Gardenfors U (2001) Classifying threatened species at national versus global levels. Trends Ecol Evol 16:511-516

Georges JY, Fossette S, Billes A, Ferraroli S and others (2007) Meta-analysis of movements in Atlantic leatherback turtles during the nesting season: conservation implications. Mar Ecol Prog Ser 338:225-232

Godley BJ, Broderick AC, Frauenstein R, Glen F, Hays GC (2002) Reproductive seasonality and sexual dimorphism in green turtles. Mar Ecol Prog Ser 226:125-133
Godley BJ, Blumenthal JM, Broderick AC, Coyne MS, Godfrey $\mathrm{MH}$, Hawkes LA, Witt MJ (2008) Satellite tracking of sea turtles: Where have we been and where do we go next? Endang Species Res 4:3-22

> Hays GC, Sutherland JM (1991) Remigration and beach fidelity of loggerhead sea turtles nesting on the island of Cephalonia, Greece. J Herpetol 25:232-233

Hays GC, Luschi P, Papi F, Seppia C, Marsh R (1999) Changes in behaviour during the inter-nesting and post-nesting migration for Ascension Island green turtles. Mar Ecol Prog Ser 189:263-273

- Hays GC, Akeson S, Godley GB, Luschi P, Santidrian P (2001a) The implications of location accuracy for the interpretation of satellite-tracking data. Anim Behav 61: 1035-1040

> Hays GC, Broderick AC, Glen F, Godley BJ, Nichols WJ (2001b) The movements and submergence behaviour of male green turtles at Ascension Island. Mar Biol 139: 395-399

> Hays GC, Broderick AC, Glen F, Godley BJ, Houghton JDR, Metcalfe JD (2002) Water temperature and internesting intervals for loggerhead (Caretta caretta) and green (Chelonia mydas) sea turtles. J Therm Biol 27: $429-432$

> Hays GC, Akesson S, Broderick AC, Glen F, Godley BJ, Papi F, Luschi P (2003) Island finding ability of sea turtles. Proc R Soc Lond B Biol Sci 270:S5-S7

Hays GC, Houghton JDR, Isaacs C, King RS, Lloyd C, Lovell P (2004) First records of oceanic dive profiles for leatherback turtles, Dermochelys coriacea, indicate behavioural plasticity associated with long-distance migration. Anim Behav 67:733-743

- Henwood TA (1987) Movement and seasonal changes in loggerhead turtle Caretta caretta aggregations in the vicinity of Cape Canaveral, Florida. Biol Conserv 40:191-202

Hopkins-Murphy SR, Owens DW, Murphy TM (2003) Chapter 5: Ecology of immature loggerheads on foraging grounds and adults in internesting habitat in the Eastern United States. Smithsonian Institution, Washington, DC

Hulbert IAR, French J (2001) The accuracy of GPS for wildlife telemetry and habitat mapping. J Appl Ecol 38:869-878

Hyrenbach KD, Forney KA, Dayton PK (2000) Marine protected areas and ocean basin management. Aquat Conserv Mar Freshw Ecosyst 10:437-458

James MC, Eckert SA, Myers RA (2005a) Migratory and reproductive movements of male leatherback turtles (Dermochelys coriacea). Mar Biol 147:845-853

James MC, Ottensmeyer A, Myers RA (2005b) Identification of high-use habitat and threats to leatherback sea turtles in northern waters: new directions for conservation. Ecol Lett 8:195-201

> Jensen MP, Abreu-Grobois FA, Frydenberg J, Loeschke V (2006) Microsatellites provide insight into contrasting mating patterns in arribada vs. non-arribada olive ridley sea turtle rookeries. Mol Ecol 15:2567-2575

Katselidis K, Schofield G, Margaritoulis D (2004) Loggerhead nest site fixity and intra-seasonal exchange in the rookery of Laganas Bay, Zakynthos, Greece. In: Coyne MS, Clark RD (eds) Proceedings of the Twenty-first Annual Symposium on Sea Turtle Biology and Conservation. NOAA Tech Memo NMFS-SEFSC-528, US Dept Comm, Philadelphia, PA, p 368

> Lawton JH (2007) Ecology, politics and policy. J Appl Ecol 44:465-474

Lee PLM (2008) Molecular ecology of marine turtles: a review of new approaches and future directions. J Exp Mar Biol Ecol 356:25-42 
Lee PLM, Hays GC (2004) Polyandry in a marine turtle: females make the best of a bad job. Proc Natl Acad Sci USA 101:6530-6535

Limpus CJ (1993) The green turtle, Chelonia mydas, in Queensland-breeding males in the Southern Great Barrier Reef. Wildl Res 20:513-523

> Lohmann KJ, Luschi P, Hays GC (2008) Goal navigation and island-finding in sea turtles. J Exp Mar Biol Ecol 356: 83-95

Luschi P, Hays GC, Papi F (2003) A review of long-distance movements by marine turtles, and the possible role of ocean currents. Oikos 103:293-302

Lusseau D (2004) The hidden cost of tourism: detecting longterm effects of tourism using behavioural information. Ecology and Society 9(1):2. www.ecologyandsociety.org/ vol9/iss1/art2/

Marcovaldi MA, Godfrey MH, Mrosovsky N (1997) Estimating sex ratios of loggerhead turtles in Brazil from pivotal incubation durations. Can J Zool 75:755-770

Margaritoulis D (2005) Nesting activity and reproductive output of loggerhead sea turtles, Caretta caretta, over 19 seasons (1984-2002) at Laganas Bay, Zakynthos, Greece: the largest rookery in the Mediterranean. Chelonian Conserv Biol 4:916-929

Martien KK, Taylor BL, Slooten E, Dawson S (1999) A sensitivity analysis to guide research and management for Hector's dolphin. Biol Conserv 90:183-191

Morreale SJ, Standora EA, Spotila JR, Paladino FV (1996) Migration corridor for sea turtles. Nature 384:319-320

> Mortimer JA, Portier KM (1989) Reproductive homing and internesting behavior of the green turtle (Chelonia mydas) at Ascension Island, South Atlantic Ocean. Copeia 1989: 962-977

Mrosovsky N, Provancha J (1989) Sex ratio of loggerhead sea turtles hatching on a Florida beach. Can J Zool 67: 2533-2539

Plotkin PT, Owens DW, Byles RA, Patterson R (1996) Departure of male olive ridley turtles (Lepidochelys olivacea) from a nearshore breeding ground. Herpetologica 52:1-7

Rasmussen K, Palacios DM, Calambokidis J, Saborio MT and others (2007) Southern Hemisphere humpback whales wintering off Central America: insights from water temperature into the longest mammalian migration. Biol Lett 3:302-305

Ryan PG, Petersen SL, Peters G, Gremillet D (2004) GPS tracking a marine predator: the effects of precision, resolution and sampling rate on foraging tracks of African penguins. Mar Biol 145:215-223

Sakamoto W, Bando T, Arai N, Baba N (1997) Migration paths of the adult female and male loggerhead turtles Caretta caretta determined through satellite telemetry. Fish Sci 63:547-552

Sato K, Matsuzawa Y, Tanaka H, Bando T, Minamikawa S, Sakamoto W, Naito Y (1998) Internesting intervals for loggerhead turtles, Caretta caretta, and green turtles, Chelonia mydas, are affected by temperature. Can J Zool 76:1651-1662

Schofield G, Katselidis KA, Dimopoulos P, Pantis JD, Hays GC (2006) Behaviour analysis of the loggerhead sea turtle Caretta caretta from direct in-water observation. Endang Species Res 2:71-79

Schofield G, Bishop CM, MacLean G, Brown P and others (2007) Novel GPS tracking of sea turtles as a tool for conservation management. J Exp Mar Biol Ecol 347:58-68

Schofield G, Katselidis KA, Dimopoulos P, Pantis JD (2008) Investigating the viability of photo-identification as an objective tool to study endangered sea turtle populations. J Exp Mar Biol Ecol 360:103-108

Schofield G, Bishop CM, Katselidis KA, Dimopoulos P, Pantis JD, Hays GC (2009) Microhabitat selection by sea turtles in a dynamic thermal marine environment. J Anim Ecol 78:14-21

Seminoff JA, Resendiz A, Nichols WJ (2002) Home range size of green turtles Chelonia mydas at a coastal foraging area in the Gulf of California, Mexico. Mar Ecol Prog Ser 242:253-265

Shaver DJ, Schroeder BA, Byles RA, Burchfield PM, Pena J, Marquez R, Martinez HJ (2005) Movements and home ranges of adult male Kemp's ridley sea turtles (Lepidochelys kempii) in the Gulf of Mexico investigated by satellite telemetry. Chelonian Conserv Biol 4: $817-827$

Sheppard JK, Preen AR, Marsh H, Lawler IR, Whiting SD, Jones RE (2006) Movement heterogeneity of dugongs, Dugong dugon (Mueller), over large spatial scales. J Exp Mar Biol Ecol 334:64-83

> Stoneburner DL (1982) Satellite telemetry of loggerhead sea turtle movements in the Georgia Bight. Copeia 1982: $400-408$

Sutherland WJ, Pullin AS, Dolman PM, Knight TM (2004) The need for evidence-based conservation. Trends Ecol Evol 19:305-308

> Togridou A, Hovardas T, Pantis JD (2006) Factors shaping implementation of protected area management decisions: a case study of the Zakynthos National Marine Park. Environ Conserv 33:233-243

Tremblay Y, Shaffer SA, Fowler SL, Kuhn PE and others (2006) Interpolation of animal tracking data in a fluid environment. J Exp Biol 209:128-140

van Dam RP, Diez CE (1998) Home range of immature hawksbill turtles (Eretmochelys imbricata L.) at two Caribbean islands. J Exp Mar Biol Ecol 220:15-24

Wallace BP, Williams CL, Paladino FV, Morreale SJ, Lindstrom RT, Spotila JR (2005) Bioenergetics and diving activity of internesting leatherback turtles Dermochelys coriacea at Parque Nacional Marino las Bualas, Costa Rica. J Exp Mar Biol Ecol 208:3873-3884

Whittow GC, Balazs GH (1982) Basking behavior of the Hawaiian green turtle (Chelonia mydas). Pac Sci 36: 129-139

Wood LJ, Dragicevic S (2007) GIS-based multicriteria evaluation and fuzzy sets to identify priority sites for marine protection. Biol Conserv 16:2539-2558

> Yasuda T, Arai N (2005) Fine scale tracking of marine turtles using GPS-Argos PTTs. Zool Sci 22:547-553

Zbinden JA, Aebischer A, Margaritoulis D, Arlettaz R (2007a) Insights into the management of sea turtle internesting area through satellite telemetry. Biol Conserv 137: $157-162$

Zbinden JA, Davy C, Margaritoulis D, Arlettaz R (2007b) Large spatial variation and female bias in estimated loggerhead sea turtle hatchling sex ratio of Zakynthos (Greece). Endang Species Res 3:305-312

Zbinden JA, Llargiadèr CR, Leippert F, Margaritoulis $D$, Arlettaz R (2007c) High frequency of multiple paternity in the largest rookery of Mediterranean loggerhead sea turtles. Mol Ecol 16:3703-3711

Zbinden JA, Aebischer A, Margaritoulis D, Arlettaz R (2008) Important areas at sea for adult loggerhead sea turtles in the Mediterranean Sea: satellite tracking corroborates findings from potentially biased sources. Mar Biol 153: 899-906

Submitted: May 9, 2008; Accepted: August 30, 2008

Proofs received from author(s): January 23, 2009 